\title{
Effectiveness of self-help mobile telephone applications (apps) for suicide prevention: A systematic review
}

\author{
Seyed Kazem Malakouti ${ }^{1}$, Nafee Rasouli*1(D), Mohsen Rezaeian ${ }^{2}$, Marzie Nojomi ${ }^{3}$, Behrooz Ghanbari ${ }^{4}$, \\ Azita Shahraki Mohammadi ${ }^{5}$
}

Received: 25 Oct 2019

Published: 27 Jul 2020

\section{Abstract}

Background: According to the expansion of suicide prevention applications in recent years, the aim of this study was to review randomized controlled trials (RCTs) and pretest-posttest studies that evaluated the effectiveness of suicide prevention applications.

Methods: In this systematic review, we searched online databases including Pubmed, SCOPUS, Web of Science, Chocrane Database, and Google Scholar to find randomized controlled trials and pretest-posttest studies published up to Jul 18, 2019. Randomized controlled trials and pretest-posttest of efficacy self-guided telephone applications that reported any primary and secondary outcome of suicidal thoughts and behaviors were included in the review. We evaluated the articles using the CONSORT 2010 checklist.

Results: After screening articles, 7 studies were included in this review. Four studies focused on the effectiveness of applications on suicide thoughts and attempt, 2 on effectiveness of applications on self-injury, 4 on depression and anxiety, 1 on impulsivity, and 2 on adaptive strategies. Overall, mobile phone applications were associated with reductions in suicidal ideation scores at post intervention, and enhancement of adaptive skills; however, no evidence of reduction was reported in impulsivity after use of applications.

Conclusion: Despite the differences in studies, this review showed that the use of mobile applications had an overall positive effect on reducing the risk of suicide and improving performance and health of patients.

Keywords: Smartphone application, Effectiveness, Suicide prevention, Clinical trials

Conflicts of Interest: None declared

Funding: None

*This work has been published under CC BY-NC-SA 1.0 license.

Copyright $₫$ Iran University of Medical Sciences

Cite this article as: Malakouti SK, Rasouli N, Rezaeian M, Nojomi M, Ghanbari B, Shahraki Mohammadi A. Effectiveness of self-help mobile telephone applications (apps) for suicide prevention: A systematic review Determining the effect of platelet-rich plasma (PRP) on improving endoscopic sinus surgery: A randomized clinical trial study. Med J Islam Repub Iran. 2020 (27 Jul);34:85. https://oi.org/10.47176/mjiri.34.85

\section{Introduction}

Suicide is a leading cause of death worldwide, and more

Corresponding author: Nafee Rasouli, rasouli.n@iums.ac.ir

1. Mental Health Research Centere, School of Behavioral Sciences and Mental Health (Tehran Institute of Psychiatry), Iran University of Medical Sciences, Tehran, Iran

2. Epidemiology and Biostatistics Department, Rafsanjan Medical School, Occupational Environmental Research Center, Rafsanjan University of Medical Sciences, Rafsanjan, Iran

3. Preventive Medicine and Public Health Research Center, Psychosocial Health Research Institute, Department of Community and Family Medicine, School of Medicine, Iran University of Medical Sciences, Tehran, Iran

4. Gastrointestinal and Liver Diseases Research Center, Iran University of Medical Sciences, Tehran, Iran

Student Research Committee, School of Health Management and Information Sciences, Iran University of Medical Sciences, Tehran, Iran than 800000 people die due to suicide each year (1).

$\uparrow$ What is "already known" in this topic:

Technologies of smartphones can make mental health services accessible, efficient, and improve the effects of evidence-based therapies for suicidal patients. The wide spread implementation of digital interventions without appropriate evaluation of their effectiveness can lead to the development and promotion of ineffective, or even harmful interventions.

\section{$\rightarrow$ What this article adds:}

We conducted a systematic review on the characteristics and effectiveness of mobile phone apps for suicidal ideation. Contrary to previous studies, in the present study, we only focused on mobile phone apps designed for suicide prevention except for online ones. Our study showed that use of mobile applications generally has a positive effects on reducing suicidal thoughts and behaviors and can also improve patients' performane. 
Young people are among the most influential people in the world, but suicide is the second leading cause of death among those aged 15-29 years (1). Various dimensions should be considered in the process of suicide prevention for its effectiveness (1). Evidence-based interventions can be useful in preventing suicide, but unfortunately, many people are reluctant to receive help due to social stigma (3). The use of mobile phones is common all around the world, and it is estimated that the number of mobile phone and smartphone users will reach around 1.6 and 3 billion, respectively, by 2020 (4). Technologies of smartphones can make mental health services accessible and efficient and improve the effects of evidence-based therapies $(5,6)$. Studies have shown that technologies of mobile phones are innovative tools to address some of suicide prevention challenges and can be considered to complement these interventions instead of being replaced by conventional interventions (7).

However, according to a systematic review, because the number of suicide prevention applications is increasing, such applications should be selected with regards to their content (8).

Designing of suicide prevention applications has increased in the recent years (6). Moreover, as designing such applications is time-consuming and costly, and at the same time this process is necessary to achieve the highest effectiveness, thus, it is essential to investigate the efficacy of these types of applications. Recently, some systematic reviews and meta-analyses (9-11) evaluated the efficacy of the technologies for suicide prevention, including all types of technologies such as text messages, websites, emails, social network services, personal digital assistants (PDA)-based health interventions, and online apps.

Contrary to previous studies, in the present study, we only focused on mobile phone apps designed for suicide prevention except for online ones. Studies that evaluated the effect of suicide prevention applications by the randomized controlled trial (RCTs) and pretest-posttest were included in this review.

\section{Methods}

\section{Search strategy}

We conducted a systematic search of Web of Science, Scopus, PubMed, Google Scholar and Cochrane databases. The original search was conducted up to Jul 18, 2019. In this review, the search terms used were as follow: suicide, mobile application, cell phone, computers, handheld and its equivalents. Also, for sensitive search, we used various combinations of keywords in each database. The search strategy for the PubMed database were as follow: "Mobile Applications"[Mesh] OR "Cell Phones"[Mesh] OR “Computers, Handheld"[Mesh] OR "mobile health"[Title/Abstract] OR "mhealth"[Title/Abstract] OR mhealth [Title/Abstract] OR "mobile-health" [Title/Abstract] OR smartphone*[Title/Abstract] ORmartphone*"[Title/Abstract] OR "mobile phone*"[Title/Abstract] OR "mobile-phone*" [Title/Abstract] OR “cellular phone*"[Title/Abstract] OR "cellular-phone*"[Title/Abstract] OR "smart de-
vice*"[Title/Abstract] OR "smart-device*" [Title/Abstract] OR "tablet* PC*"[Title/Abstract] OR “tablet-based" [Title/Abstract] OR "tablet* device*"[Title/Abstract].

A total of 7 articles that had the study inclusion criteria and were valid based on CONSORT (Consolidated Standards of Reporting Trials) checklist were selected. The list of databases and search strings used in this systematic review is presented in the Appendix. Also, the process of selecting the articles was based on PRISMA statement in this review.

\section{Selection criteria}

Inclusion criteria were as follows: (1) studies that used randomized controlled trial (RCT) and pretest-posttest designs; (2) studies that reported any primary and secondary outcome of suicidal thoughts and behaviors and evaluated the effectiveness, and 3) evaluating the effectiveness of self-care suicide prevention mobile phone applications.

Exclusion criteria were as follow: (1) studies that examined the effectiveness of other technologies used for suicidal prevention; (2) those that merely reported the application design and / or its feasibility; and (3) qualitative studies, systematic reviews, and meta-analysis conducted in this field.

\section{Quality assessment}

CONSORT checklist was used to evaluate the selected papers that were designed using a randomized controlled trial (RCT) (12). All included RCT studies were assessed for compliance with the 2010 guidelines of the CONSORT statement. To measure compliance, the author gave a score of " 0 " if the item was not present, " 1 " if the property was partly present, and " 2 " if the item was clearly present. To demonstrate this scoring method, the CONSORT item 3 states, "Eligibility criteria for participants and the settings and locations where the data were collected." Minimum and maximum scores were 19 and 37, respectively. Studies that scored higher than 19 in the 6 main sections after being evaluated by 2 authors were included in the final analysis.

\section{Data extraction}

The articles were examined by one of the researchers and the process of searching and extracting articles was reviewed by another researcher. First, the titles of all the articles found $(n=603)$ were examined; then, irrelevent and repetitive cases were removed. At the next stage, the abstracts of the remaining articles $(n=317)$ and the full texts of 14 studies that met the inclusion criteria were studied, and finally 7 eligible studies were included in the final analysis. The screening process of titles and abstracts was done by EndNoteX8 software.

The information extracted from each article included the information of each study (sample size, and follow-up duration), intervention characteristics (application name, application summary, and details of interventions), primary effects (suicide thoughts and actions), secondary effects (symptoms of depression, self-injury, anxiety, etc.), and the scales used to evaluate the effects of each intervention. 


\section{Results}

\section{Search results}

The electronic search strategy is outlined in the Appendix. Initially, a total of 603 potentially relevant records were identified in Pubmed database we used various combinations of keywords such as suicide, mobile application, cell phone, computers, handheld, and their equivalents in the titles and abstracts, which resulted in finding 110 articles. In Web of Science we also used the combination of the mentioned keywords in the titles and abstracts of 144 articles and obtained 17 articles. In Scopus, we used the same combination of keywords and obtained 133 articles. In Google Scholar, were also extracted 100 in its first 10 pages. Moreover, in Cochrane we found 99 articles. In addition, the reference lists of final articles were manually searched for additional studies and 3 relevant studies were found. Figure 1 showed the process of selecting the articles included based on PRISMA statement in this review.

\section{Final studies}

The details of each study are reported in Table 1 . The following information has been reported from each of the 7 articles: corresponding author, year of publication, country, name and characteristics of the application, purpose of the study, number of samples, type of study, duration of follow-up, type of intervention in each group, and study results. Among the 7 applications in the studies, 2 were designed in Australia $(13,14), 3$ in the USA (15-17), 1 in Denmark (18), and 1 in the UK (19).

Three articles were conducted using pretest-posttest methods and follow-up, but the method of other articles was randomized control therapy (RCT).

All designed applications except 1 (17), had a contact button with crisis lines and or emergency numbers' list or links to social support resources. Four of the apps had the opportunity to evaluate the person by themselves on a daily basis. Also the apps used cognitive behavioral therapy (CBT), dialectical behavior therapy (DBT), mindfulness based cognitive behavioural therapy (MCBT) and relaxation techniques. Moreover, they provided training for recognizing thoughts and feelings and controlling them and identifying suicide risk symptoms. They also included educational videos and images, and had the ability to personalize information. These applications were specifically for effective suicide and self-injury prevention.

The results of the reviewed demonstrated the effectiveness of the applications on reducing suicide thoughts and attempts $(14-16,18,20)$ impulsive attempt (self-injury) $(17,19)$, depression and anxiety $(13,17-19)$, impulsivity (13), and increasing adaptive strategies $(14,15)$.

The follow-up duration of the study groups varied from 1 week to 4 months. In 4 articles (15-18) treatment as usual (TAU), along with using an application, was used in the experimental group. The applications included in the present study used evidenced-based approaches, including CBT, DBT, and MCBT techniques for suicide prevention.

\section{Applications}

Hope Box application is one of CBT's techniques to combat suicidal thoughts, whose usefulness has been proven in CBT. In this technique, people use a box to be reminded of activities that have been helpful to them. This box is customized and one can save images, videos, and effective writing in one's language in the program. This program consists of 6 general sections. Other techniques used in this application are relaxation techniques, functional games for distracting the senses, and inspirational quotes (15).

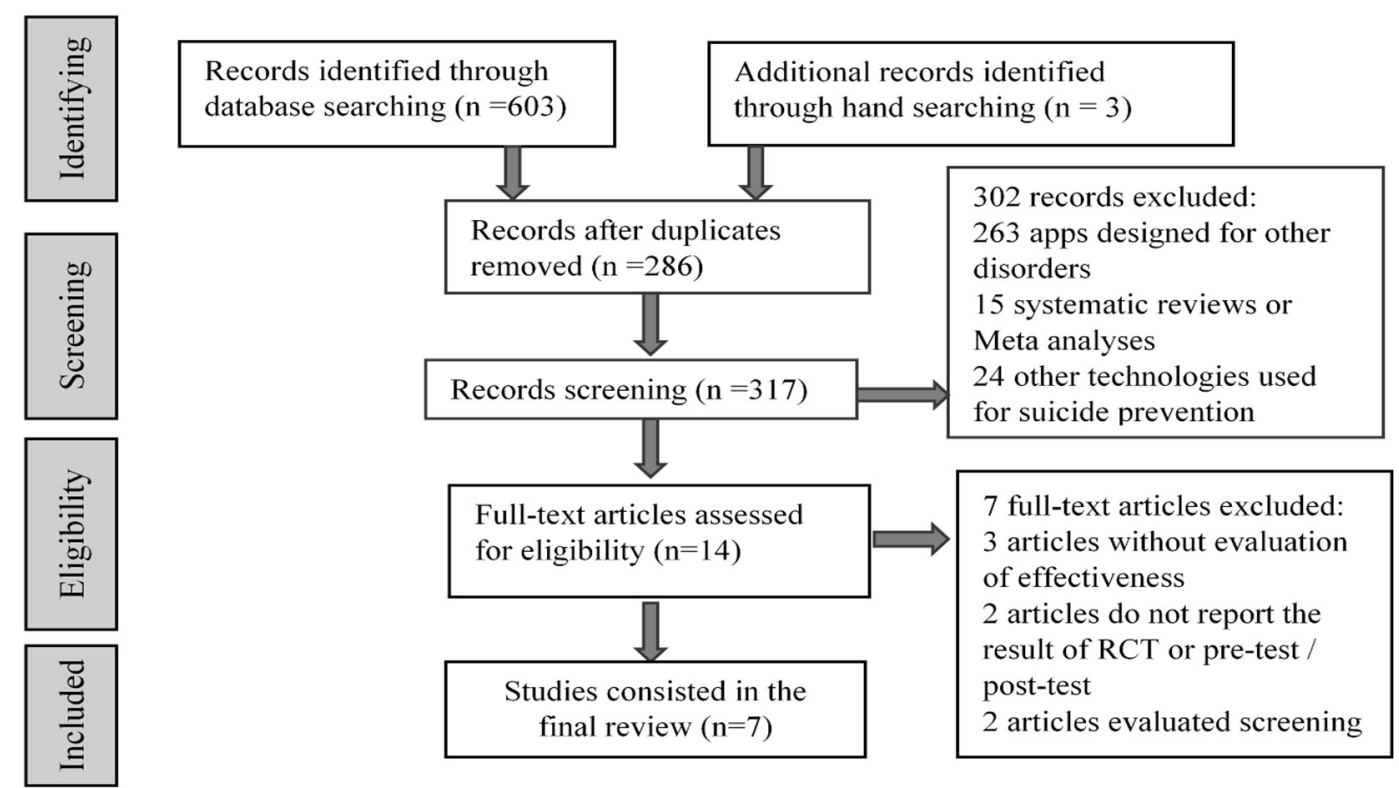

Fig. 1. PRISMA flow chart of study 
Table 1. Characteristics of included studies

\begin{tabular}{|c|c|c|c|c|c|c|c|c|}
\hline First author & Country & App name and details & Study aims & Exercise (n) & $\begin{array}{l}\text { Control } \\
\text { (n) }\end{array}$ & Design & Measurement tools & $\begin{array}{l}\text { Outcome } \\
\text { measure }\end{array}$ \\
\hline $\begin{array}{l}\text { Paul Stallard } \\
\text { et al. } \\
2018 \text { (19) }\end{array}$ & United Kingdom & $\begin{array}{l}\text { BlueIce, } \\
\text { - provides a personalized } \\
\text { toolbox of strategies based on } \\
\text { CBT and DBT. } \\
\text { - includes a mood diary, menu } \\
\text { of personalized mood-lifting } \\
\text { activities } \\
\text {-automatic routing through } \\
\text { safety checks to delay or prevent } \\
\text { self-harm. }\end{array}$ & $\begin{array}{l}\text { Assess the acceptability, } \\
\text { safety, use of BlueIce and } \\
\text { effects on the primary } \\
\text { outcome of self-harm and } \\
\text { the secondary outcomes of } \\
\text { psychological functioning. }\end{array}$ & 29 & - & $\begin{array}{l}\text { - Pre-test/post- } \\
\text { test } \\
-2 \text { weeks (post } \\
\text { familiarization) } \\
\text { and again at } 12 \\
\text { weeks (post } \\
\text { use) Follow-up, } \\
\text {-Self-report and } \\
\text { Parent-report }\end{array}$ & $\begin{array}{l}\text { The Mood and Feel- } \\
\text { ings Questionnaire } \\
\text { (MFQ), the Revised } \\
\text { Child Anxiety and } \\
\text { Depression Scale } \\
\text { (RCADS), the } \\
\text { Strengths and Difficul- } \\
\text { ties Questionnaire } \\
\text { (SDQ) }\end{array}$ & $\begin{array}{l}\text { Self-report: } \\
\text {-Rate of self-harming: }(15 \%) \text { had completely } \\
\text { stopped, with a further }(58 \%) \text { reporting less fre- } \\
\text { quent acts of self-harm at follow-up } \\
\text {-Depression, Anxiety, and Behavior significant } \\
\text { mean difference of } 4.91 \text { ( } \mathrm{t} 31=2.11 ; \mathrm{P}=.04 ; 95 \% \mathrm{CI} \\
0.17-9.64) \text { on (MFQ) and } 13.53 \text { on symptoms of } \\
\text { anxiety (RCADS) (t30=3.76; P=.001; } 95 \% \mathrm{CI} \\
6.17-20.90) \text { emotional subscale ( } \mathrm{t} 29=2.90 \text {; } \\
\mathrm{P}=.007 ; 95 \% \mathrm{CI} 0.25-1.44) \text {. } \\
\text { Parent-report: } \\
\text { - mean difference of } 0.92 \text { on the emotional sub- } \\
\text { scale }(95 \% \mathrm{CI} 0.083-1.75 ; \mathrm{t} 11=2.42 ; \mathrm{P}=.03), 2.61 \\
\text { on the peer relationship subscale }(95 \% \mathrm{CI} 0.334- \\
4.90 ; \mathrm{t} 12=2.50 ; \mathrm{P}=.03) \text {, and } 4.08 \text { on the total score } \\
(95 \% \mathrm{CI} 2.16-6.01 ; \mathrm{t} 11=4.67 ; \mathrm{P}=.001) \text {. }\end{array}$ \\
\hline $\begin{array}{l}\text { Joseph Tighe } \\
\text { et al. } 2016 \\
\text { (13) }\end{array}$ & Australia & $\begin{array}{l}\text { Ibobbly, } \\
\text {-self-assessments } \\
\text {-emergency contact information } \\
\text { for several 24-hour helplines } \\
\text { - Techniques for identify } \\
\text { thoughts, feelings and behav- } \\
\text { iours and taught to regulate their } \\
\text { emotions. }\end{array}$ & $\begin{array}{l}\text { Evaluate the effectiveness } \\
\text { of a self-help mobile app } \\
\text { (ibobbly) targeting suicid- } \\
\text { al ideation, depression, } \\
\text { psychological distress and } \\
\text { impulsivity among Indig- } \\
\text { enous youth in remote } \\
\text { Australia. }\end{array}$ & 31 & 30 & $\begin{array}{l}\text {-RCT, } \\
6 \text { Weeks Fol- } \\
\text { low-up }\end{array}$ & $\begin{array}{l}\text { The depressive symp- } \\
\text { tom inventory- } \\
\text { suicidality subscale } \\
\text { (DSI-SS), Patient } \\
\text { Health Questionnaire } \\
\text { (PHQ-9), the Kessler } \\
\text { psychological distress } \\
\text { scale (K10), the Barratt } \\
\text { Impulsiveness Scale- } \\
11 \text { (BIS-11) }\end{array}$ & $\begin{array}{l}\text {-Preintervention and postintervention changes on } \\
\text { the (DSI-SS) in the ibobbly arm }(\mathrm{t}=2.40 ; \mathrm{df}=58.1 \text {; } \\
\mathrm{p}=0.01) \text {, these differences compared with the wait- } \\
\text { list arm }(\mathrm{t}=1.05 ; \mathrm{df}=57.8 ; \mathrm{p}=0.2),- \text { significant } \\
\text { reductions in PHQ- } 9(\mathrm{t}=2.79 ; \mathrm{df}=56.9 ; \mathrm{p}=0.0072) \\
\text { and } \mathrm{K} 10 \text { scores }(\mathrm{t}=2.44 ; \mathrm{df}=57.5 ; \mathrm{p}=0.01) \text {, } \\
\text { No differences were observed in impulsivity }\end{array}$ \\
\hline $\begin{array}{l}\text { Gllenna a. } \\
\text { Melvin et al. } \\
2018(21)\end{array}$ & Australia & $\begin{array}{l}\text { BeyondNow, } \\
\text {-Red emergency } \\
\text { phone button on each page } \\
\text {-A platform for individuals to } \\
\text { create, edit, access, and share } \\
\text { personalized safety plan } \\
\text { - Able to list warning signs, } \\
\text { reasons to live, ways to limit } \\
\text { access to lethal means, coping } \\
\text { strategies, and personal and } \\
\text { professional contacts. }\end{array}$ & $\begin{array}{l}\text { Evaluated the effective- } \\
\text { ness of integrating the } \\
\text { BeyondNow safety plan- } \\
\text { ning smartphone app }\end{array}$ & 36 & - & $\begin{array}{l}\text { - Pre-test/post- } \\
\text { test }, \\
-2 \text { months } \\
\text { Follow-up }\end{array}$ & $\begin{array}{l}\text { Columbia-suicide } \\
\text { severity rating scale } \\
\text { (C-SSRS), } \\
\text { The Suicide Related } \\
\text { Coping Scale (SRCS), } \\
\text { The Suicide Resilience } \\
\text { Inventory-25 (SRI- } \\
\text { 25), The Coping Strat- } \\
\text { egy Usage Question- } \\
\text { naire (CSUQ) }\end{array}$ & $\begin{array}{l}\text { Significant reductions in severity of ideation (Base- } \\
\text { line mean }=4.33 \text {, Postintervention mean }=2.29) \\
(\mathrm{p}>0.001) \text {, and intensity of ideation (Baseline } \\
\text { mean= 19.46, Postintervention }=17.44)(\mathrm{p}=0.01) \text {, } \\
\text { increase Mean of total coping(Baseline }=57.58 \text {, } \\
\text { Postintervention }=68.14) \text { internal coping, exter- } \\
\text { nal coping, total resilience (Baseline }=81.61 \text {, } \\
\text { Postintervention= } 96.64) \text {, } \\
\text { A significant increase in the frequency of suicide- } \\
\text { related coping strategy use was observed between } \\
\text { baseline }(\mathrm{M}=22.29, \mathrm{SD}=4.61) \\
\text { and postintervention }(\mathrm{M}=27.29, \mathrm{SD}=4.45) \\
\text { assessments; } \mathrm{t}(13)=-3.56, \mathrm{p}<.01 .\end{array}$ \\
\hline
\end{tabular}




\begin{tabular}{|c|c|c|c|c|c|c|c|c|}
\hline First author & Country & App name and details & Study aims & $\begin{array}{c}\text { Exercise } \\
(\mathrm{n})\end{array}$ & $\begin{array}{c}\text { Control } \\
(\mathrm{n})\end{array}$ & Design & Measurement tools & $\begin{array}{l}\text { Outcome } \\
\text { measure }\end{array}$ \\
\hline $\begin{array}{l}\text { Mia } \\
\text { S.O'Toole et } \\
\text { al. } \\
2018(18)\end{array}$ & Denmark & $\begin{array}{l}\text { LifeApp'tite, } \\
\text { - Psychoeducation about suicid- } \\
\text { al thoughts and ways to handle } \\
\text { situations } \\
\text {-Self-rating scales } \\
\text { - a safety plan } \\
\text { - Digital hope kit } \\
\text { - Quick access to an overview of } \\
\text { places to seek help } \\
\text { - A methods library divided into } \\
\text { two sections of self-help exer- } \\
\text { cises. }\end{array}$ & $\begin{array}{l}\text { Evaluate the effect of an } \\
\text { app-assisted suicide } \\
\text { prevention treatment on } \\
\text { suicide risk and depres- } \\
\text { sion }\end{array}$ & 60 & 69 & $\begin{array}{l}\text { RCT, } \\
\text { (TAU+APP) VS. } \\
\text { (TAU), } \\
-4 \text { month Follow- } \\
\text { up }\end{array}$ & $\begin{array}{l}\text { The Suicide Status Form II- } \\
\text { R (SSF), The Major Depres- } \\
\text { sion Inventory (MDI) }\end{array}$ & $\begin{array}{l}\text { - Mean of Suicide risk: } \\
\text { TAU+APP group: (pre: } 18.7 \text { Follow up:14) } \\
\text { TAU group (pre: } 18, \text { Follow up: } 12.7 \text { ) } \\
\text { - Mean of Depression: } \\
\text { TAU+APP group: (pre: } 34.5, \\
\text { Follow up: } 20.5 \text { ), TAU group (pre: } 32.9 \text {, } \\
\text { Follow up: 18.1) }\end{array}$ \\
\hline $\begin{array}{l}\text { Lauren M. } \\
\text { Denneson et } \\
\text { al. } 2018(15)\end{array}$ & USA & $\begin{array}{l}\text { Virtual Hope Box (VHB), con- } \\
\text { tained six primary sections } \\
\text { designed to collectively provide } \\
\text { support, comfort, } \\
\text { distraction, or relaxation by } \\
\text { using audio, video, pictures, } \\
\text { games, mindfulness exercises, } \\
\text { messages, inspirational quotes, } \\
\text { coping } \\
\text { Statements, and other media } \\
\text { content. }\end{array}$ & $\begin{array}{l}\text { Examined the indirect } \\
\text { effect of the Virtual Hope } \\
\text { Box (VHB) } \\
\text { on suicidal ideation, me- } \\
\text { diated through coping } \\
\text { self-efficacy }\end{array}$ & 50 & 55 & $\begin{array}{l}\text { RCT, (APP) VS. } \\
\text { TAU, 3, 6, and } 12 \\
\text { Weeks Follow-up }\end{array}$ & $\begin{array}{l}\text { Both the suicidal ideation } \\
\text { Severity(BSS), the coping } \\
\text { self-efficacy (CSE) }\end{array}$ & $\begin{array}{l}\text { - Mean of Coping self-efficacy: } \\
\text { VHB ( Baseline: } 10.57,12 \text { weeks: } 14.78 \text { ) } \\
\text { eTAU (Baseline: } 11.83,12 \text { weeks: } 12.89 \text { ) } \\
\text { - Mean of Suicidal Ideation: VHB ( Base- } \\
\text { line: } 3.31 \text {, } \\
\text { 12 weeks: } 3.16 \text { ) } \\
\text { eTAU (Baseline: } 3.58,12 \text { weeks: } 3.20 \text { ) }\end{array}$ \\
\hline $\begin{array}{l}\text { Betsy D. } \\
\text { Kennard et al. } \\
2018(16)\end{array}$ & USA & $\begin{array}{l}\text { BRITE, } \\
\text {-convenient access to distress } \\
\text { tolerance strategies, } \\
\text { - emotion regulation skills } \\
\text { - safety plan } \\
\text { - daily text messages to rate } \\
\text { level of emotional distress } \\
\text { - offered a range of distress } \\
\text { tolerance and emotion regula- } \\
\text { tion skills, with the ability to } \\
\text { upload support } \\
\text { materials (videos, web sites, and } \\
\text { photographs) }\end{array}$ & $\begin{array}{l}\text { Evaluate of an inpatient } \\
\text { Intervention for suicidal } \\
\text { adolescents, As Safe as } \\
\text { Possible (ASAP), sup- } \\
\text { ported by a smartphone } \\
\text { app (BRITE) to reduce } \\
\text { suicide attempts following } \\
\text { hospital discharge. }\end{array}$ & 34 & 32 & $\begin{array}{l}\text { RCT } \\
- \text { app (BRITE) } \\
+\quad(\text { TAU) VS. } \\
\text { Treatment as } \\
\text { Usual (TAU), } \\
-4,12,24 \text { weeks } \\
\text { Follow-up }\end{array}$ & $\begin{array}{l}\text { The Youth Self-Report scale } \\
\text { (YSR), the } \\
\text { five-item Screen for Child } \\
\text { Anxiety Related Emotional } \\
\text { Disorders scale (SCARED), } \\
\text { the nine-item Patient } \\
\text { Health Questionnair (PHQ- } \\
\text { 9), CRAFFT, Regulation of } \\
\text { Emotions Questionnaire } \\
\text { (ERQ), Distress Tolerance } \\
\text { Scale (DTS), Multidimen- } \\
\text { sional Scale of Perceived } \\
\text { Social Support (MSPSS). }\end{array}$ & $\begin{array}{l}\text { - Rates of suicide attempts after hospital } \\
\text { discharge: (ASAP) plus treatment } \\
\text { as usual group: } \mathrm{N}=5[16.1 \%] \text {; treatment as } \\
\text { usual group: } \\
\mathrm{N}=9[31 \%] ; \mathrm{x} 2=1.86 \\
\text {, } \mathrm{p}=0.17 .) \\
\text { - Past history of a suicide attempt moderated } \\
\text { treatment outcome with a stronger, albeit } \\
\text { nonsignificant, effect of ASA } \\
\text { Plus treatment as usual ( } \mathrm{p}=0.06 \text { ). } \\
\text { - the ASAP plus treatment as usual group } \\
\text { had a longer time to suicide attempt ( } \mathrm{p}=0.03 \text { ) } \\
\text { - increase in social support over time in the } \\
\text { ASAP plus treatment as usual group } \\
\text { ( }=0.01 \text { ) }\end{array}$ \\
\hline
\end{tabular}




\begin{tabular}{|c|c|c|c|c|c|c|c|c|}
\hline First author & Country & App name and details & Study aims & Exercise (n) & $\begin{array}{l}\text { Control } \\
\text { (n) }\end{array}$ & Design & Measurement tools & $\begin{array}{l}\text { Outcome } \\
\text { measure }\end{array}$ \\
\hline $\begin{array}{l}\text { Shireen L. } \\
\text { Rizvi et al. } \\
2011 \text { (17) }\end{array}$ & USA & $\begin{array}{l}\text { DBT Coach, } \\
\text { includes content from all four } \\
\text { modules of } \\
\text { Linehan's revised skills manu- } \\
\text { al: mindfulness, distress } \\
\text { tolerance, emotion regulation } \\
\text { and interpersonal effectiveness } \\
\text { skills }\end{array}$ & $\begin{array}{l}\text { Test initial feasibility, } \\
\text { acceptability, and imme- } \\
\text { diate effects of the DBT } \\
\text { Coach } \\
\text { when integrated into a } \\
\text { standard DBT program for } \\
\text { suicidal individuals with } \\
\text { BPD }\end{array}$ & 16 & - & $\begin{array}{l}\text { - pre-test/post- } \\
\text { test } \\
-\quad 3 \text { month } \\
\text { follow-up }\end{array}$ & $\begin{array}{l}\text { The Diagnostic and } \\
\text { Statistical Manual } \\
\text { of Mental Disorders } \\
\text { (SCID), the General } \\
\text { Severity Index (GSI), } \\
\text { the Difficulties in } \\
\text { Emotion Regulation } \\
\text { Scale (DERS), The } \\
\text { Self-Injurious } \\
\text { Thoughts } \\
\text { and Behaviors Inter- } \\
\text { view (SITBI), The } \\
\text { DBT Ways of Coping } \\
\text { Checklist (DBT- } \\
\text { WCCL) }\end{array}$ & $\begin{array}{l}\text { - Results indicated a } \\
\text { significant reduction in participants' distress rat- } \\
\text { ings at the end of } \\
\text { DBT Coach sessions; pre-Coach }(\mathrm{M}=4.62),(\mathrm{SD}= \\
2.67) \text {, postCoach }(\mathrm{M} 3.14)(\mathrm{SD}=2.19),(\mathrm{B}=1.49 \text {, } \\
\mathrm{SE} 0.16), \\
\mathrm{T}(721) 9.02, \mathrm{p}<.001 \\
\text { - analyses revealed a significant reduction in urges } \\
\text { to self-harm following app use (although urges } \\
\text { were relatively low at both time points); pre-Coach } \\
(\mathrm{M}=1.75 \text {, } \\
\mathrm{SD}=2.67), \text { post-Coach }(\mathrm{M}=1.13, \mathrm{SD}=1.97),(\mathrm{B} \\
=0.61, \\
\mathrm{SE}=0.15), \mathrm{t}(721) 4.10, \mathrm{p}<.001 .\end{array}$ \\
\hline
\end{tabular}


BlueIce BlueIce application is also composed of a toolbox featuring evidence-centric techniques for reducing stress, relaxation and mindfulness techniques, daily mood recording, and regularly evaluate reminding. This application is effective in reducing stress and mood control in those who impulsively attempt suicide with self-injury (19).

IBobbly application uses psychological training approach to teach how to get informed and share thoughts and feelings and provides a tool box for managing them. This application also provides a section for recording the activity program and tools to monitor the progress in this direction. It also provides an opportunity for selfassessment to keep track of changes in mood and stress levels (13).

Beyond Now is an application suitable for those with suicidal thoughts and behaviors. This application uses the Safety Planning Intervention (SPI) guidelines. This type of intervention (SPI) involves recognizing personal risk signs, causes of survival for each person, internal adaptive strategies, socialization strategies for social support etc. SPI techniques are helpful for preventing suicidal behaviors. Each of these sections is included in the application and can be customized (21).

LifeApp'tite application uses a psychological training approach to teach about suicidal thoughts and how to manage them in patients and in those who are in contact with these patients. This app also allows evaluating oneself by using 2 MDI and SSF measures, and recording daily sleep, appetite, and stress levels; and its use can be automatically recalled. One can create a digital hope kit that includes positive thoughts and memories for use in times when one is very disappointed. The techniques of problem-solving, distraction, mindfulness, ACT, planning for enjoyable activities, reducing social isolation etc. are used and automatically and daily the app informs the users that after performing these techniques, their mood will be evaluated (18).

Brite application is designed to increase coping strategies for adolescents hospitalized due to suicide attempt. By teaching the emotional setting techniques, this application raises stress tolerance in individuals. Safety planning techniques are also used to allow daily evaluation of stress levels by texting. The users can customize photos, videos, and websites in the application. The content of DBT coach application is also based on 4 models of Linehan (2015), including techniques of mindfulness, stress tolerance, emotional regulation, and interpersonal skills. It also includes items for measuring stress levels in real time, and the degree to which individuals tend to self-injury, which displays a person's score on a scale (16).

\section{Analysis of clinical results}

The risk of suicide: In one of the pretest-posttest studies (21), the mean \pm SD severity of suicidal thoughts and intensity of suicidal thoughts showed a significant reduction after 2 months follow-up. A significant improvement in the suicide-related coping strategy was observed between baseline and postintervention assessments.

In the study conducted in Australia (13), suicidal thoughts significantly reduced after the intervention in the group receiving Ibobbly application, but this reduction was significantly lower than the control group. Also, significant reductions were observed in PHQ-9 and K10 scores, but no differences in impulsivity.

In a paper by O'Toole et al (18), while the mean of suicide risk in the experimental group reduced in the 4-month follow-up (before intervention: 18.7, Follow up: 14); however, this reduction was less in the control group receiving routine treatment (intervention: 18, Follow-up: 12.7).

In the study conducted in 2018 in the United States (15), the results showed that the mean suicidal thoughts showed no significant difference in the experimental group (baseline $=3.31,12$ weeks $=3.16$ ) and control group (baseline $=3.58,12$ weeks $=3.20$ ) after a 12 -week follow-up.

In the study (16) that compared the amount of thoughts and suicide actions after discharge from hospital in 2 groups, the rate of suicide action in the group who received the usual treatment in addition to the application was $16 \%$ and it was $31 \%$ in the control group. Also, the rate of suicidal thoughts was $75.9 \%$ and $67.7 \%$ in the experimental and control groups, respectively. This resulted in a greater reduction in suicide thoughts and actions in the group receiving the application compared to the control group. Nevertheless, the differences were not significant. Moreover, treatment in the group receiving the application had a strong but insignificant effect on the history of suicide action.

In the study (19) that evaluated the effect of BlueIce application using uncontrolled RCT method, self-injury evaluation in a 12 -month follow-up showed that $15 \%$ of the participants completely stopped self-injury and it reduced by $58 \%$.

\section{Depression and anxiety}

The results of some studies on anxiety, depression, and its subscales have shown a significant reduction $(3,4,6)$. In one of these studies, which was used BlueIce application in the experimental group and followed them for 12 weeks, this reduction was significant in depression and anxiety of the experimental group compared to the control group (19). Tighe et al. (13) used the 2-arm RCT method with a 6-week follow-up and found a significant reduction in depression and anxiety of the experimental group compared to the control group. Nonetheless, in one study (18), while the mean of the experimental group was reduced in the depression scale (before intervention: 34.5, follow-up: 20.5), this reduction was lower than the control group who received TAU without using application (before intervention: 32.9, Follow-up: 18.1).

\section{Adaptive abilities}

Melvin et al (21), showed a significant increase over time for the total suicide-related coping scale and subscales. Older age was associated with higher scores on the total suicide-related coping scale, but age was not related to the subscales (internal or external suicide-related coping).

In another study (16) that compared social support in 2 groups, this variable had a significant increase in the ex- 
perimental group. Meanwhile, the mean coping selfefficacy in the study that used Hope-Box app showed an increase in the experimental group (baseline: 10.57, 12 weeks: 14.78) compared to the control group (baseline: 11.83, 12 weeks: 12.89). (15).

\section{Discussion}

This study was conducted to systematically review the papers that evaluated the effectiveness of suicide prevention mobile apps on suicide risk and other secondary effects by RCT and pretest-posttest methods. Seven studies were included in the final analysis, among which 3 were conducted with pretest and posttest design. One of the studies (19) evaluated the effectiveness of the apps that could be applied to prevent suicide on the number of impulsive suicide attempts (self-injury), depression, and anxiety. In general, all conducted evaluations showed a positive effect of apps on reducing suicide risk and other outcomes. In one study, however, no significant difference was observed in the level of depression between intervention and control groups, and the reduction of suicide risk was higher in the control group (18). However, in other studies, a significant decrease was reported in depression and anxiety in the experimental group. In a meta-analysis study that evaluated the effectiveness of apps in reducing depression symptoms using the RCT method, a significant reduction was reported in depression symptoms in the group that used an application compared to the control group (22).

The studies included in the present review showed the effect of apps on reducing the risk of suicide, including suicidal thoughts, behavior, and history, which has been reported to be significant in some of them $(13,14,16)$. Some studies investigated the effect of other technologies, including internet programs, SMS, and telephone followups, on suicide prevention and reported a reduction in suicidal thoughts and associated diseases $(9,23-25)$. Some studies have reported no significant reduction in other digital interventions, such as online intervention $(17,26$, 27 , which can indicate a more significant effect of mobile apps because of their easier access and attractiveness than other online, internet, and texting interventions in mental health programs including suicide prevention.

To prevent suicide, in addition to the importance of reducing and preventing risk factors, it is important to consider the protective factors and the ability to adapt to difficult conditions. In some of the findings reviewed in this study, in addition to evaluating the effectiveness of applications on reducing risk factors, they measured the increase in adaptive abilities. In follow-ups, the use of applications has significantly increased coping capabilities and protective factors such as stress tolerance, adaptive strategies, adaptive self-efficacy, and increased social support for patients $(14,15)$. One of these studies (15) reported that the application of the Virtual Hop Box (VHB) probably reduces suicidal thoughts in the experimental group because of the increased coping selfefficacy, but this effect may decrease over time.

Overall, this review study showed that researches conducted by the pretest-posttest method reported a signifi- cant reduction in the severity of suicide ideation and impulsive suicide attempts (self-harm) $(17,19,21)$. However, in the RCTs $(15,18)$ no significant difference was reported in suicide risk and suicidal ideation of the groups that used an app versus treatment as usual and the group that used treatment as usual without the app.

This study and previous systematic reviews $(26,28)$ showed that a limited number of apps had been specifically designed to prevent suicide, most of which have not been designed with high-quality methods to evaluate the effectiveness of apps. A systematic review studied on the apps developed in 2017 revealed that there are 124 suicide prevention apps worldwide, among which only 20 apps have been specifically designed to prevent suicide (28). Among these, only few apps have been evaluated using effective methods. Some studies have only assessed users' satisfaction with the quality of the apps $(27,29)$. Several review studies have evaluated the effectiveness of various technologies in reducing the risk of suicide $(9,26)$, However, to date, no review study specifically addressed the effectiveness of apps in preventing suicide.

Overall, further studies should be conducted using RCT and pretest/posttest methods to make an overall conclusion. Nevertheless, considering the growing popularity of smartphones apps, especially among adolescents and the impossibility of referring some individuals for in-person treatment due to social stigma, long-distance to service providers, mistrust in the therapist-patient relationship, etc., designing these types of apps and evaluating their effectiveness can be an innovative approach to reducing suicide, particularly in adolescents.

\section{Conclusion}

Further studies are needed to determine the effectiveness of suicide prevention applications. These mobile applications should be deployment efficient and assess the effectiveness by RCTs and adequate follow-up time and sample size. Although studies have largely demonstrated the effectiveness of suicide prevention applications, but due to insufficient number of RCT studies, it is better to use these applications as supplements of treatment as usual (TAU).

\section{Conflict of Interests}

The authors declare that they have no competing interests.

\section{References}

1. Organization WH. Preventing suicide: A global imperative: World Health Organization; 2014.

2. Organization WH. Mental health action plan 2013-2020. Geneva: World Health Organization; 2013. This document was produced in response to the World Health Assembly Resolutions WHA66 8 and WHA65 4, provides the necessary framework for improving mental health globally from the government to individual level, and provides a strong rationale for collaborative care. 2014

3. Tadros G, Jolley D. The stigma of suicide. BJPsych. 2001;179(2):178.

4. Ericsson A. Ericsson mobility report: On the pulse of the Networked Society. Ericsson, Sweden, Tech Rep EAB-14. 2015;61078.

5. Luxton DD, McCann RA, Bush NE, Mishkind MC, Reger GM. mHealth for mental health: Integrating smartphone technology in behavioral healthcare. Prof Psychol Res Pr. 2011;42(6):505.

6. Luxton DD, June JD, Kinn JT. Technology-based suicide prevention: 
current applications and future directions. TELEMED E-HEALTH. 2011;17(1):50-4.

7. Luxton DD, June JD, Chalker SA. Mobile health technologies for suicide prevention: feature review and recommendations for use in clinical care. Curr Treat Options Psychiatry. 2015;2(4):349-62.

8. Larsen ME, Nicholas J, Christensen H. A systematic assessment of smartphone tools for suicide prevention. PloS One. 2016;11(4): 0152285 .

9. Witt K, Spittal MJ, Carter G, Pirkis J, Hetrick S, Currier D, et al. Effectiveness of online and mobile telephone applications ('apps') for the self-management of suicidal ideation and self-harm: a systematic review and meta-analysis. BMC Psychiatry. 2017;17(1):297.

10. Torok M, Han J, Baker S, Werner-Seidler A, Wong I, Larsen ME, et al. Suicide prevention using self-guided digital interventions: a systematic review and meta-analysis of randomised controlled trials. Lancet Digit Health. 2020;2(1):e25-e36.

11. Arshad U, Gauntlett J, Husain N, Chaudhry N, Taylor PJ. A Systematic Review of the Evidence Supporting Mobile-and InternetBased Psychological Interventions For Self-Harm. Suicide Life Threat Behav. 2019; vol(no):pp.

12. Schulz KF, Altman DG, Moher D. CONSORT 2010 statement: updated guidelines for reporting parallel group randomised trials. BMC Med. 2010;8(1):18.

13. Tighe J, Shand F, Ridani R, Mackinnon A, De La Mata N, Christensen H. Ibobbly mobile health intervention for suicide prevention in Australian Indigenous youth: a pilot randomised controlled trial. BMJ Open. 2017;7(1):e013518.

14. Melvin GA, Gresham D, Beaton S, Coles J, Tonge BJ, Gordon MS, et al. Evaluating the feasibility and effectiveness of an Australian safety planning smartphone application: a pilot study within a tertiary mental health service. Suicide Life Threat Behav. 2018; vol(no):pp.

15. Denneson LM, Smolenski DJ, Bauer BW, Dobscha SK, Bush NE. The mediating role of coping self-efficacy in hope box use and suicidal ideation severity. Arch Suicide Res. 2019;23(2):234-46.

16. Kennard BD, Goldstein T, Foxwell AA, McMakin DL, Wolfe K, Biernesser C, et al. As Safe as Possible (ASAP): a brief app-supported inpatient intervention to prevent postdischarge suicidal behavior in hospitalized, suicidal adolescents. Am J Psychiatry. 2018;175(9):86472 .

17. Rizvi SL, Hughes CD, Thomas MC. The DBT Coach mobile application as an adjunct to treatment for suicidal and self-injuring individuals with borderline personality disorder: A preliminary evaluation and challenges to client utilization. Psychol Serv. 2016;13(4):380.

18. O'Toole MS, Arendt MB, Pedersen CM. Testing an app-assisted treatment for suicide prevention in a randomized controlled trial: effects on suicide risk and depression. Behav Ther. 2019;50(2):421-9.

19. Stallard P, Porter J, Grist R. A smartphone app (BlueIce) for young people who self-harm: open phase 1 pre-post trial. JMIR mhealth uhealth. 2018;6(1):e32.

20. Pauwels K, Aerts S, Muijzers E, De Jaegere E, van Heeringen K, Portzky G. BackUp: Development and evaluation of a smart-phone application for coping with suicidal crises. PLoS One. 2017;12(6):e0178144.

21. Melvin GA, Gresham D, Beaton S, Coles J, Tonge BJ, Gordon MS, et al. Evaluating the feasibility and effectiveness of an Australian safety planning smartphone application: A pilot study within a tertiary mental health service. Suicide Life Threat Behav. 2019;49(3):846-58.

22. Firth J, Torous J, Nicholas J, Carney R, Pratap A, Rosenbaum S, et al. The efficacy of smartphone-based mental health interventions for depressive symptoms: a meta-analysis of randomized controlled trials. World Psychiatry. 2017;16(3):287-98.

23. Kreuze E, Jenkins C, Gregoski M, York J, Mueller M, Lamis DA, et al. Technology-enhanced suicide prevention interventions: a systematic review. J Telemed Telecare. 2017;23(6):605-17.

24. Hoek W, Marko M, Fogel J, Schuurmans J, Gladstone T, Bradford $\mathrm{N}$, et al. Randomized controlled trial of primary care physician motivational interviewing versus brief advice to engage adolescents with an Internet-based depression prevention intervention: 6-month outcomes and predictors of improvement. Transl Res. 2011;158(6):315-25.

25. Saulsberry A, Marko-Holguin M, Blomeke K, Hinkle C, Fogel J, Gladstone $\mathrm{T}$, et al. Randomized clinical trial of a primary care internet-based intervention to prevent adolescent depression: one-year outcomes. J Can Acad Child Adolesc Psychiatry. 2013;22(2):106.
26. Perry Y, Werner-Seidler A, Calear AL, Christensen H. Web-based and mobile suicide prevention interventions for young people: a systematic review. J Can Acad Child Adolesc Psychiatry. 2016;25(2):73.

27. McManama O'Brien KH, LeCloux M, Ross A, Gironda C, Wharff EA. A pilot study of the acceptability and usability of a smartphone application intervention for suicidal adolescents and their parents. Arch Suicide Res. 2017;21(2):254-64.

28. de la Torre I, Castillo G, Arambarri J, López-Coronado M, Franco MA. Mobile apps for suicide prevention: Review of virtual stores and literature. JMIR mhealth uhealth. 2017:5(10):e130.

29. Kennard BD, Biernesser C, Wolfe KL, Foxwell AA, Craddock Lee SJ, Rial KV, et al. Developing a brief suicide prevention intervention and mobile phone application: a qualitative report. Technol Hum Serv. 2015;33(4):345-57. 
Appendix

PubMed, 110 Articles

1. "suicid*" [Title/Abstract] OR "suicide"[Mesh] OR "suicide"[Title/Abstract]

2. "Mobile Applications"[Mesh] OR "Cell Phones"[Mesh] OR “Computers, Handheld”[Mesh] OR "mobile health"[Title/Abstract] OR "mhealth"[Title/Abstract] OR mhealth [Title/Abstract] OR "mobile-health" [Title/Abstract] OR smartphone*[Title/Abstract] OR "smartphone*"[Title/Abstract] OR “mobile phone*"[Title/Abstract] OR “mobile-phone*" [Title/Abstract] OR "cellular phone*”[Title/Abstract] OR “cellularphone*"[Title/Abstract] OR "smart device*"[Title/Abstract] OR "smart-device*" [Title/Abstract] OR "tablet* PC*"[Title/Abstract] OR "tablet-based" [Title/Abstract] OR "tablet* device*"[Title/Abstract]

3. 1 AND 2

SCOPUS, 133 Articles

(TITLE-ABS (suicid*) OR TITLE-ABS (suicide)) AND ( TITLE-ABS ("Mobile Applications" ) OR TITLE-ABS ( "Cell Phones" ) OR TITLEABS ( computers, AND handheld) OR TITLE-ABS ( "mobile health" ) OR TITLE-ABS ( "m-health" ) OR TITLE-ABS ( mhealth ) OR TITLEABS ("mobile-health" ) OR TITLE-ABS ("smartphone*") OR TITLE-ABS ("smart-phone*" ) OR TITLE-ABS ("mobile phone*" ) OR TITLEABS ( "mobile-phone*" ) OR TITLE-ABS ( "cellular phone*" ) OR TITLE-ABS ( "cellular-phone*" ) OR TITLE-ABS ( "smart device*" ) OR TITLE-ABS ("smart-device*") OR TITLE-ABS ("tablet* PC*" ) OR TITLE-ABS ("tablet-based" ) OR TITLE-ABS ( "tablet* device*" ) ) AND ( LIMIT-TO ( DOCTYPE, "ar" ) OR LIMIT-TO ( DOCTYPE, "re" ) ) AND ( LIMIT-TO ( LANGUAGE, "English" ) )

Web of Sciences, 144 Articles

1. $\mathrm{TS}=($ suicid $*$ OR suicide $)$

2. TS=("Mobile Applications" OR "Cell Phones" OR "Computers, Handheld" OR "mobile health" OR "m-health" OR "mhealth" OR "mobile-health" OR "smartphone*" OR "smart-phone*" OR "mobile phone*" OR "mobile-phone*" OR "cellular phone*" OR "cellular-phone*" OR "smart device*" OR "smart-device*" OR "tablet* PC*" OR "tablet-based" OR "tablet* device*")

3. \#2 AND \#1

Cochrane Database, 99 Articles

suicide AND ("Mobile Applications" OR "Cell Phones" OR "Computers, handheld" OR "mobile health" OR "m-health" OR "mhealth" OR "mobilehealth" OR "smartphone" OR "smart-phone" OR " mobile-phone" OR "mobile phone" OR "cellular phone" OR "smart device")

17 Articles by search and review article limitation

Title, abstract, keywords: suicide AND ("Mobile Applications" OR "Cell Phones" OR "Computers, handheld" OR "mobile health" OR "m-health" OR "mhealth" OR "mobile-health" OR "smartphone" OR "smart-phone" OR " mobile-phone" OR "mobile phone" OR "cellular phone" OR "smart device"

Googlescholar, The first 10 page, 100 Articles

suicide AND OR smart device "Mobile Applications" OR "Cell Phones" OR "Computers handheld" OR "mobile health" OR mhealth OR mhealth OR "mobile health" OR smartphone OR "smart phone" OR "mobile phone" OR "mobile phone" OR "cellular phone" 